\title{
Diarrhetic shellfish poisoning (DSP) associated with a subsurface bloom of Dinophysis norvegica in Bedford Basin, eastern Canada
}

\author{
D. V. Subba Rao ${ }^{1}$, Youlian Pan ${ }^{1,2}$, V. Zitko ${ }^{3}$, G. Bugden ${ }^{1}$, K. Mackeigan ${ }^{3}$ \\ 'Department of Fisheries and Oceans, Bedford Institute of Oceanography, PO Box 1006, Dartmouth, Nova Scotia, \\ Canada B2Y 4 A2 \\ ${ }^{2}$ Department of Biology, Dalhousie University, Halifax, Nova Scotia, Canada B3H 4J1 \\ ${ }^{3}$ Department of Fisheries and Oceans, Biological Station, St. Andrews, New Brunswick, Canada E0G 2X0
}

\begin{abstract}
The first diarrhetic shellfish poisoning (DSP) red tide associated with the dinoflagellate Dinophysis norvegica recorded for eastern Canada occurred in Bedford Basin from 20 July to 3 August 1990. The abundance of $D$. norvegica was up to ca $0.5 \times 10^{6}$ cells $l^{-1}$, which is the highest ever reported. It constituted up to $88 \%$ of the total diatoms and dinoflagellates, and was most abundant at ca $10 \mathrm{~m}$ depth in the pycnocline at almost all the stations in the Basin. The temporal pattern of particle size spectra matched closely the abundance of $D$. norvegica. Okadaic acid $(O A)$ content in the vertical plankton tows ranged from 0.78 to $6.08 \mu \mathrm{g} \mathrm{OA} \mathrm{g}{ }^{-1}$ dry plankton. The $\mathrm{OA}$ in the digestive tract of exposed experimental scallops Placopecten magellanicus was $320 \mathrm{ng} \mathrm{g}^{-1}$ on $27 \mathrm{July}$ and increased to 469 $\mathrm{ng} \mathrm{\textrm {g } ^ { - 1 }}$ on 3 August 1990. The toxin's temporal distribution in scallops was the inverse of that in the plankton samples. OA content in scallops increased in spite of its decrease in plankton, which suggests that the scallops accumulated OA but depurated slowly. The potential for a DSP episode exists in Nova Scotian waters if a similar growth of toxicogenic $D$. norvegica occurs in areas of consumable molluscs.
\end{abstract}

\section{INTRODUCTION}

On the eastern coast of North America, particularly in the Bay of Fundy, recurrence of paralytic shellfish poisoning (PSP) caused by chronic blooms of the dinoflagellate Alexandrium tamarense is well known (White \& Maranda 1978, White 1986). Diarrhetic shellfish poisoning (DSP), which also has harmful effects on shellfish consumers and mariculturists, is caused by other dinoflagellates, such as species of Dinophysis (Lee et al. 1989) and Prorocentrum lima (Marr et al. 1992). Until recently DSP was unknown on Nova Scotian coasts. DSP has been studied in Japan (Yasumoto et al. 1978), northern Europe (Lassus et al. 1985, Lee et al. 1989), and the northern Adriatic (Sedmek \& Fanuko 1991). There was circumstantial evidence for the association of DSP toxicity with Dinophysis spp. (Maranda \& Shimizu 1987. Freudenthal \& Jijina 1988) along the eastern coast of the United States. More recently, Cembella (1989) found the oc- currence of okadaic acid (OA), a major DSP toxin, in Dinophysis spp. in the plankton tows from the lower estuary and Gulf of St. Lawrence. Quilliam et al. (1991) reported the incidence of DSP in cultured mussels from Mahone Bay, Nova Scotia, in 1990, but without any record of a toxicogenic algal bloom; however, Marr et al. (1992) isolated and cultured Prorocentrum lima from the same area during the same season, which yielded OA. There is no previous report of an occurrence of $D$. norvegica in red-tide proportions on the Canadian Atlantic coast.

We were alerted of a red-water phenomenon during studies on the filtration rates, growth and mortality of sea scallops Placopecten magellanicus stocked in tanks receiving water from Bedford Basin, Nova Scotia (Cranford \& Gordon 1992). A cursory examination of this water under the microscope revealed a high concentration of Dinophysis norvegica. As a part of the ongoing phytoplankton monitoring program by the Department of Fisheries and Oceans, Canada, we in- 
vestigated phytoplankton abundance, species composition and occurrence of okadaic acid in the bloom dominated by $D$. norvegica and in experimental scaliops from 24 July to 3 August 1990 in Bedford Basin.

\section{MATERIALS AND METHODS}

During the sampling periods, winds were moderate $\left(<10 \mathrm{~km} \mathrm{~h}^{-1}\right)$ from the south during 27 July and 1 August; they were steady, stronger ( 30 to $40 \mathrm{~km} \mathrm{~h}^{-1}$ ) and westerly from 2 to 3 August. Samples were collected in the morning at about 09:00 h at 3 stations (Fig. 1) on alternate days between 24 July and 3 August 1990 when Dinophysis norvegica occurred in red-tide proportions in the Bedford Basin. Discolouration of the water at $10 \mathrm{~m}$ was similar to PANTONE OAAC-C (a mix of cyan 0.0, magenta 6.0, yellow 6.0 and black 11.5; Anonymous 1990) but was faint at the surface. Using a Sea-Bird Electronics Profiler 25 (SBE $25)$, vertical profiles of temperature, conductivity and in vivo chlorophyll fluorescence were obtained. Water samples were collected from 1, 5, 10, 15 and $25 \mathrm{~m}$ with a 5 I Niskin sampler. Ideally, samples would have been collected from the maximum chlorophyll a layer that varied between 7 and $9 \mathrm{~m}$ on the various occasions (see Figs. 2D, 3D \& 4D). Unfortunately, this was not done because fluorescence profiles were not processed while occupying the station. The $5 \mathrm{~m}$ and $10 \mathrm{~m}$ water samples were collected from the edges of these layers, although not from the peak itself.

Phytoplankton were identified and enumerated under an inverted plankton microscope. Chlorophyll a in the samples was determined on $90 \%$ acetone extracts (Strickland \& Parsons 1972) of algae retained on GF/F Whatman filters and were used for calibration of in vivo fluorescence readings to chlorophyll a values. Size spectra of particles were determined with a Model Ta II Coulter counter fitted with a $140 \mu \mathrm{m}$ tube.

Vertical plankton tows were taken from the euphotic layer $(0$ to $25 \mathrm{~m}$ ) in Bedford Basin using a $0.5 \mathrm{~m}$ Nitex net $(20 \mu \mathrm{m})$ and then frozen for toxin determination. The contents of each sample were transferred to a $50 \mathrm{ml}$ stainless steel centrifuge tube, and spun at $3400 \mathrm{rpm}(\mathrm{ca} 1500 \times \mathrm{g})$ for $10 \mathrm{~min}$. The supernatant fluid was drawn off and discarded. Five ml of absolute methanol were blended with the pellet and the mix. ture was centrifuged for another $10 \mathrm{~min}$. The resulting supernatant fluid was drawn off and saved. This process was repeated using $5 \mathrm{ml}$ of $45 \%$ methanol. The 2 methanolic extracts were combined and tested for the presence of OA employing the DSP-check Quick Test Kit (UBE Industries Ltd, Tokyo, Japan). This kit makes use of an ELISA (Enzyme-Linked Immuno-sorbent Assay) method involving a monoclonal antibody with

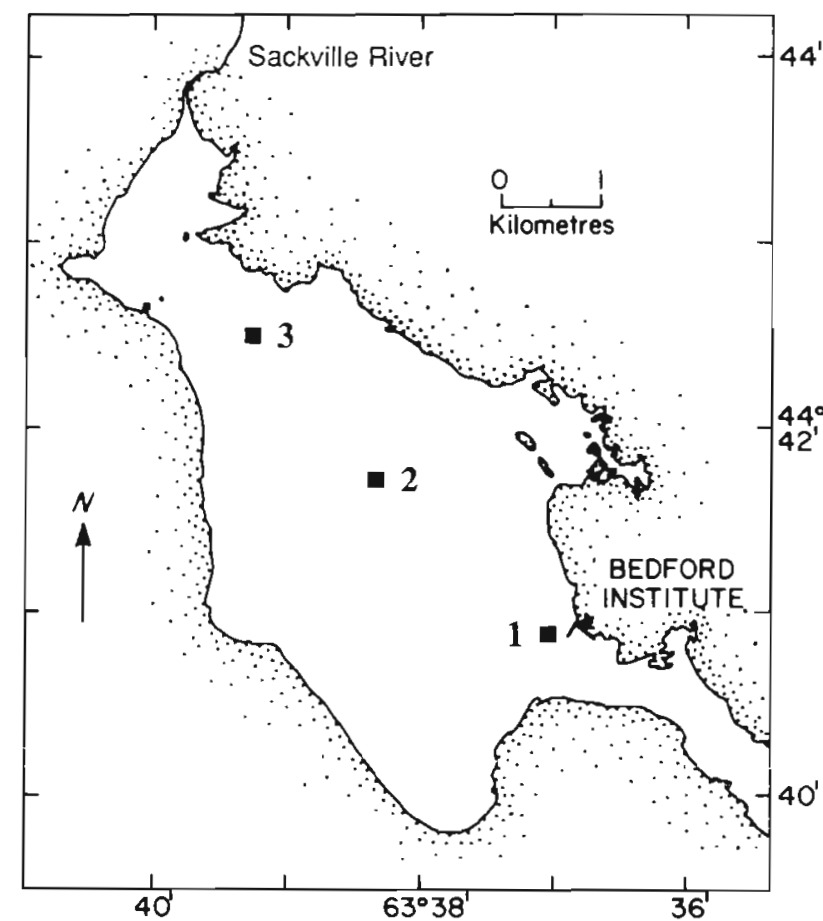

Fig. 1. Sampling stations ( $)$ in the Bedford Basin

high specificity for OA and dinophysistoxin-1 (DTX-1) (Uda et al. 1989, Shestowsky et al. 1992, Tubaro et al 1992). In addition to the 10 and $100 \mathrm{ppb} O A$ standard provided with the kit, 3 additional standards of 25,50 and $75 \mathrm{ppb}$ were made by diluting $0.25,0.5$ and $0.75 \mathrm{ml}$ of $100 \mathrm{ppb}$ standard to $1 \mathrm{ml}$ respectively. We designated the total toxins (OA and/or DTX-1) detected by this method as OA, following Tubaro et al. (1992), because the antibody is not able to distinguish $\mathrm{OA}$ and DTX-1 (Uda et al. 1989).

Sea scallops Placopecten magellanicus $100 \pm$ $2.0 \mathrm{~mm}$ ), collected from Sable Island Bank off Nova Scotia, Canada, were held in a flow-through flume tank at the Bedford Institute of Oceanography before the bloom developed and provided with Bedford Basin water from $10 \mathrm{~m}$ depth (Stn 1). Thus, scallops were exposed to the various phases of the bloom. Three scallops were removed at each sampling time on 27 and 30 July and 1 and 3 August 1990 and stored frozen. Subsequently, the digestive glands were removed, pooled, transferred to a $50 \mathrm{ml}$ disposable polypropylene centrifuge tube and homogenized in distilled water. The contents were transferred to a $125 \mathrm{ml}$ Erlenmeyer flask, and twice as much absolute methanol as sample was added and allowed to stand overnight (ca $12 \mathrm{~h}$ ) at room temperature. The contents were then centrifuged for $10 \mathrm{~min}$ at $3400 \mathrm{rpm}$ (ca $1500 \times \mathrm{g}$ ). The supernatant fluid was taken and tested for the presence of DSP using the UBE kit. 
Aliquots of net tows used for toxin analyses were enumerated under the microscope for the various taxa. Aliquots of the same slurries were air-dried at $60^{\circ} \mathrm{C}$ for $24 \mathrm{~h}$, then cooled in a desiccator and weighed. From plankton counts and dry weight of samples, a conversion factor of $4.38 \times 10^{7}$ Dinophysis norvegica $\mathrm{g}^{-1}$ dry weight was calculated. This permitted conversion of OA content in plankton sample to OA content $D$. norvegica cells.

\section{RESULTS}

During this study, there was very little wind mixing in the Bedford Basin as evident from the very shallow surface layer (Figs. 2, 3 \& 4). The Basin waters were highly stratified during the bloom. There were slight differences between the head of the Basin (Stn 3, Fig. 4) and the outer Basin (Stn 2, Fig. 3). The depth of the surface mixed layer was usually greater $(>5.5 \mathrm{~m})$ in the outer Basin (25 July, 3 August) than near the head of the Basin ( $<3.5 \mathrm{~m}$ on 25 July, $2 \mathrm{~m}$ on 3 August), where the fresh water input from the Sackville River was important in initiating and maintaining stratification. At all stations, a large density change from 2 to $2.5 \sigma_{\top}$ units was noticed between 5 and $15 \mathrm{~m}$. Temperature and salinity contributed approximately equally to this density change

The size spectra (Fig. 5) of the particulate matter pumped from Stn 1 in the Basin at $10 \mathrm{~m}$ depth showed a clear peak between 25 and $50 \mu \mathrm{m}$; the integrated particle concentration gradually increased from 4.4 ppm on 25 July to 9.2 ppm on 30 July and then decreased to 4.0 ppm on 3 August 1990 . Patterns of particle spectra were the same at Stns $2 \& 3$. Considering the sizes of the organisms ( 28 to $54 \mu \mathrm{m}$ ) and their relative abundance in the total phytoplankton, it was concluded that the dinoflagellates, especially Dinophysis norvegica, occurring in bloom proportions $\left(166 \times 10^{3}\right.$ to $456 \times 10^{3}$ cells $^{-1}$ ) contributed heavily to the peaks, which was confirmed by microscopic observation. Although there was no direct correlation between particulate matter concentration and total phytoplankton numbers, there was a consonance of abundance between total diatoms and dinoflagellates, and $D$. norvegica (Fig. 6).

The total abundance of phytoplankton cells (Table 1) ranged from $644 \times 10^{3}$ cells $\mathrm{l}^{-1}$ at $25 \mathrm{~m}$, Stn 2 on 30 July to $11931 \times 10^{3}$ cells $\mathrm{l}^{-1}$ at $10 \mathrm{~m}$, Stn 2 on 3 August. Algae of $<10 \mu \mathrm{m}$ diameter (microflagellates and picoplankters) contributed to $>85 \%$ of total numbers (Table 1). Larger algae represented by diatoms and dinoflagellates ranged between $15.2 \times 10^{3}$ cells $\mathrm{l}^{-1}$ at $25 \mathrm{~m}, \mathrm{Stn} 3$ on 25 July and $606.6 \times 10^{3}$ cells $1^{-1}$ at $5 \mathrm{~m}$, Stn 3 on 1 August (Table 1). On most occasions, these larger algae reached a maximum at about $10 \mathrm{~m}$ followed by a decrease till $25 \mathrm{~m}$. The relative abundance of Dinophysis norvegica ranged from 0.1 to $88 \%$ of total diatoms and dinoflagellates (Table 1).

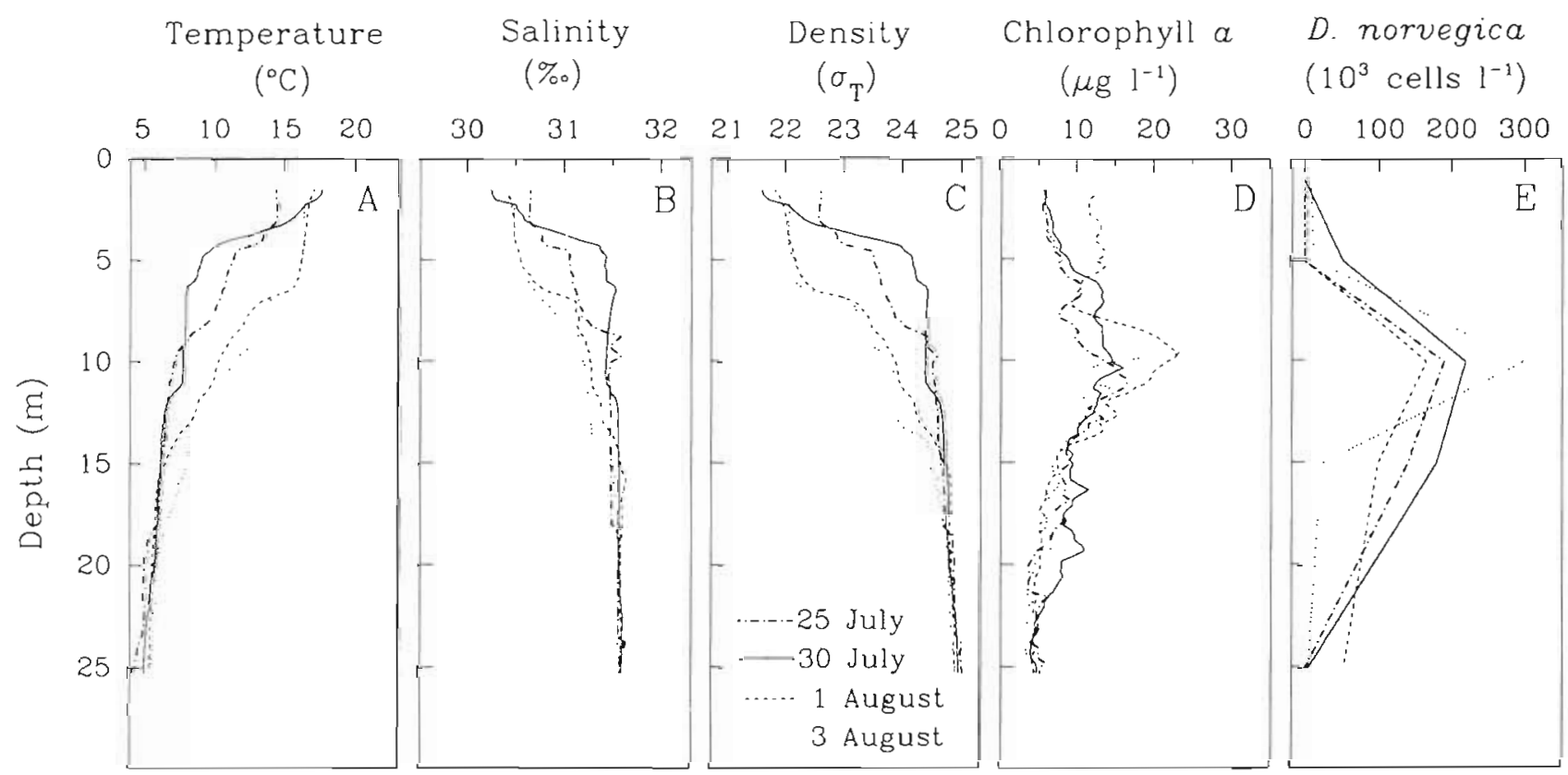

Fig. 2. Vertical profiles of temperature (A), salinity (B), density (C), chlorophyll a (D) and Dinophysis norvegica abundance (E) between 25 July and 3 August at Stn 1 

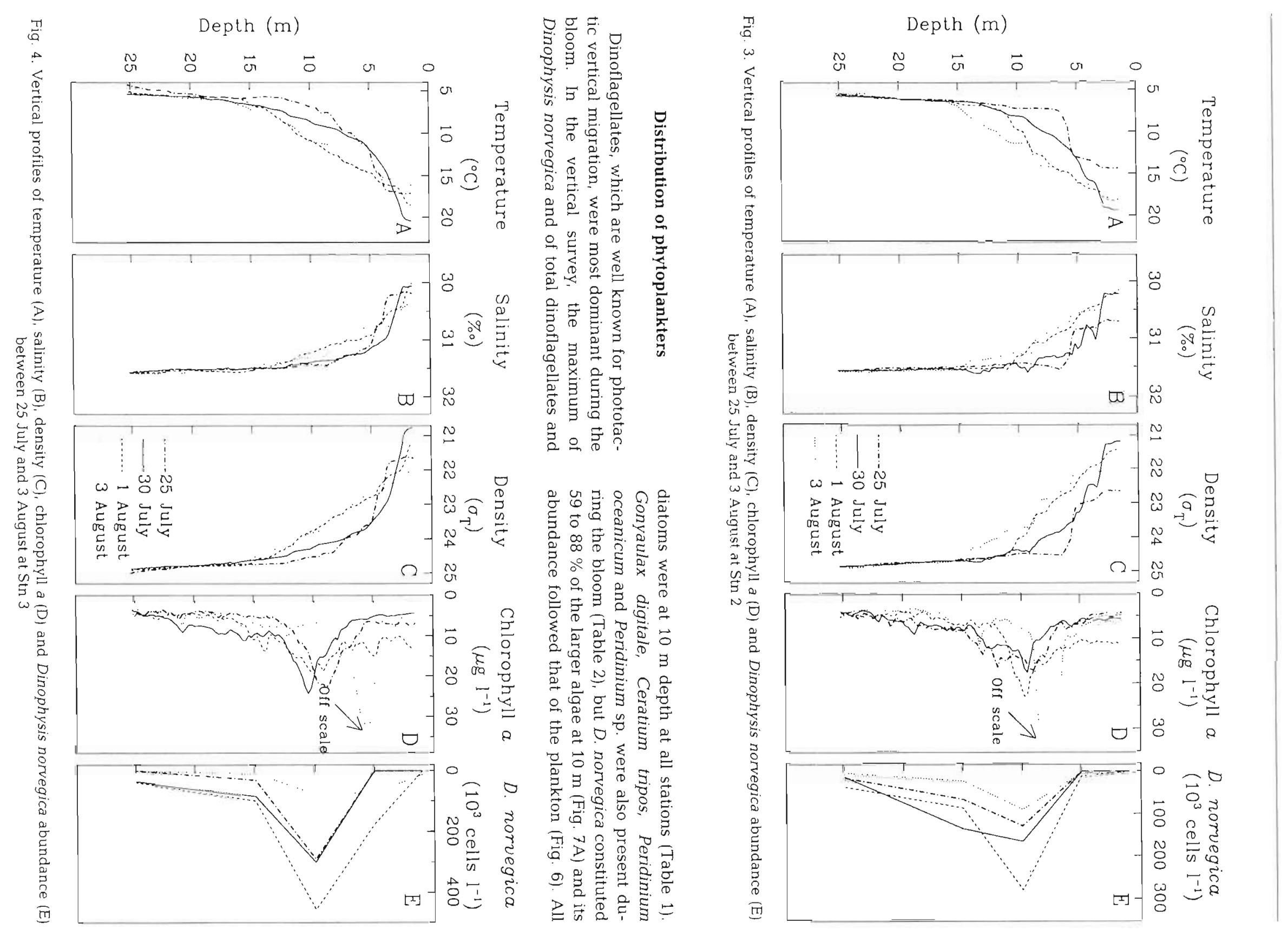

ล

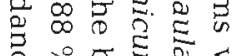

(0)

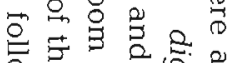

年

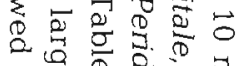

乎

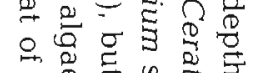

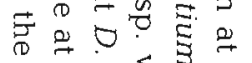

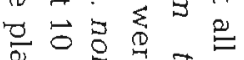

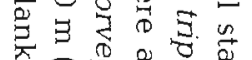

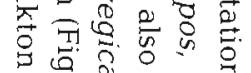

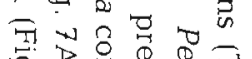

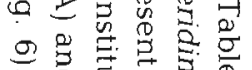

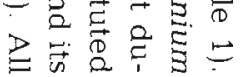


discrete samples taken during this study contained $D$. norvegica which ranged between 0.12 and $456 \times 10^{3}$ cells $1^{-1}$. Generally, D. norvegica was more abundant at Stn 3 than at Stns $1 \& 2$.

Vertical distribution of chlorophyll a calculated from fluorescence profiles (Figs, 2D, 3D \& 4D) showed that chlorophyll a increased from the surface usually reaching a peak near $10 \mathrm{~m}$ during 25 July through 1 August and at about 5 to $8 \mathrm{~m}$ on 3 August 1990. Below the chlorophyll maximum, the values decreased with increasing depth and were fairly constant between 17 and $25 \mathrm{~m}$. There was a gradual increase in the peak chlorophyll a levels between 25 July and 3 August. On 3 August, the maximum of $33.5 \mu \mathrm{g} \mathrm{l}^{-1}$ occurred at $10 \mathrm{~m}$ depth at $\operatorname{Stn} 1$; the fluorescence signals between 7 and $9 \mathrm{~m}$ were too high to read on the SBE 25 at Stns $2 \& 3$ on the same day, possibly due to aggregation of dinoflagellates at these depths. These data demonstrated the utility of locating and demarcating lenses of water with aggregations of dinoflagellate populations such as Dinophysis norvegica, Gonyaulax digitale and Ceratium tripos.

\section{DSP toxin}

$\mathrm{OA}$ in the plankton tows ranged between 0.78 and $6.08 \mu \mathrm{g} \mathrm{g}^{-1} \mathrm{dry}$ weight of plankton. The highest level was in the part of the bloom located near sheltered water (Stn 1) on 25 July. By 30 July the toxin levels at all stations were high (2.89 to $\left.4.77 \mathrm{\mu g} \mathrm{g}^{-1}\right)$. This was followed by a gradual decrease and an even distribution ( 2 to $2.63 \mu \mathrm{g} \mathrm{g}^{-1}$ ) on 1 August. Toxin levels were

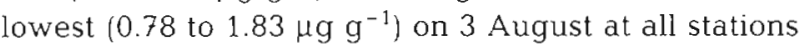
(Fig. 7B)

$O A$ in the digestive tracts of the scallops ranged from 307 to $332 \mathrm{ng} \mathrm{g}^{-1}$ between 27 July and 1 August and increased to $469 \mathrm{ng} \mathrm{g}^{-1}$ on 3 August. The temporal pattern of $\mathrm{OA}$ in scallops was the inverse of that of plankton samples (Fig. 7B).

\section{DISCUSSION}

The population concentration of Dinophysis norvegica with a maximum of $456 \times 10^{3}$ cells $\mathrm{I}^{-1}$ was the highest ever recorded (Table 3 ) and very likely more cells were present in the fluorescence peaks. These data also suggest that $D$. norvegica in Nova Scotian waters attain a maximum during July through September. The biomass magnitude of this red

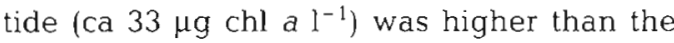
usual spring bloom values (Subba Rao \& Smith 1987). Evidence of size spectra and their correspondence to the abundance of $D$. norveg-

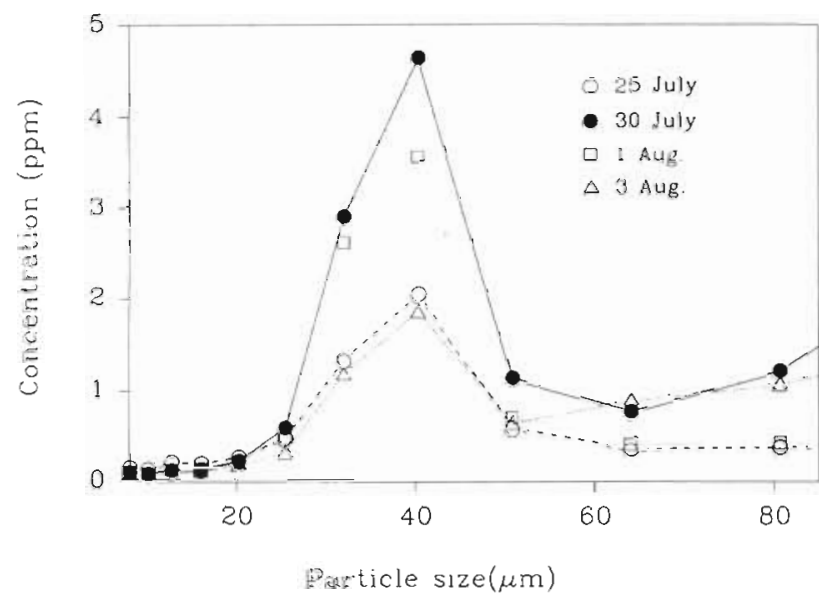

Fig, 5. Particle size spectra of seawater from $10 \mathrm{~m}$ at $\mathrm{Stn} 1$ between 25 July and 3 August

ica in the seawater showed that this DSP toxicogenic red tide was attributable to a bloom of the dinoflagellate $D$. norvegica.

Comparison of total phytoplankton cells and Dinophysis norvegica abundance (Table 1) with the fluorescence profiles revealed a lack of correspondence particularly in the depth of their maxima, for example on 25 July and 3 August (Fig. 2D, E). As stated earlier, the true nature of these fluorescence peaks could not be analyzed because of their position between discrete sampling depths. Also the depth of maximum cell abundance varied between 1 and $15 \mathrm{~m}$ (Table 1) depending on the station and the sampling day which is consistent with the observations on spatial and temporal inhomogeneities in phytoplankton distribution in the Bedford Basin (Platt 1975).

Some of these peaks could be due to vertical migration and aggregation of Dinophysis norvegica populations, an important adaptation mechanism to daily solar radiation fluctuation. During this bloom, solar radiation ( $\mathrm{MJ} \mathrm{m} \mathrm{m}^{-2} \mathrm{~d}^{-1}$ ) and the duration of bright sun-

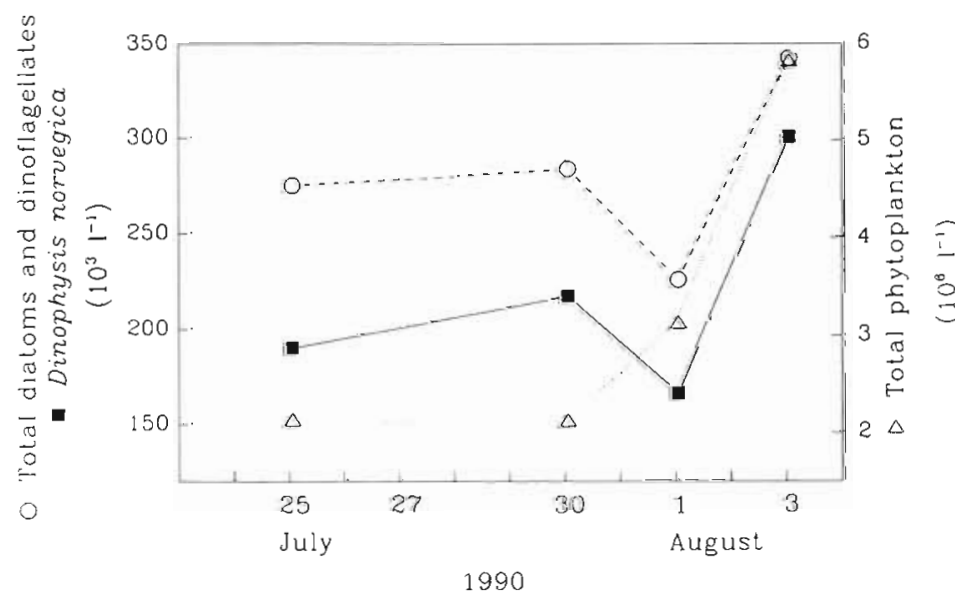

Fig. 6. Phytoplankton cell concentration at $\operatorname{Stn} 1$ at $10 \mathrm{~m}$ depth 


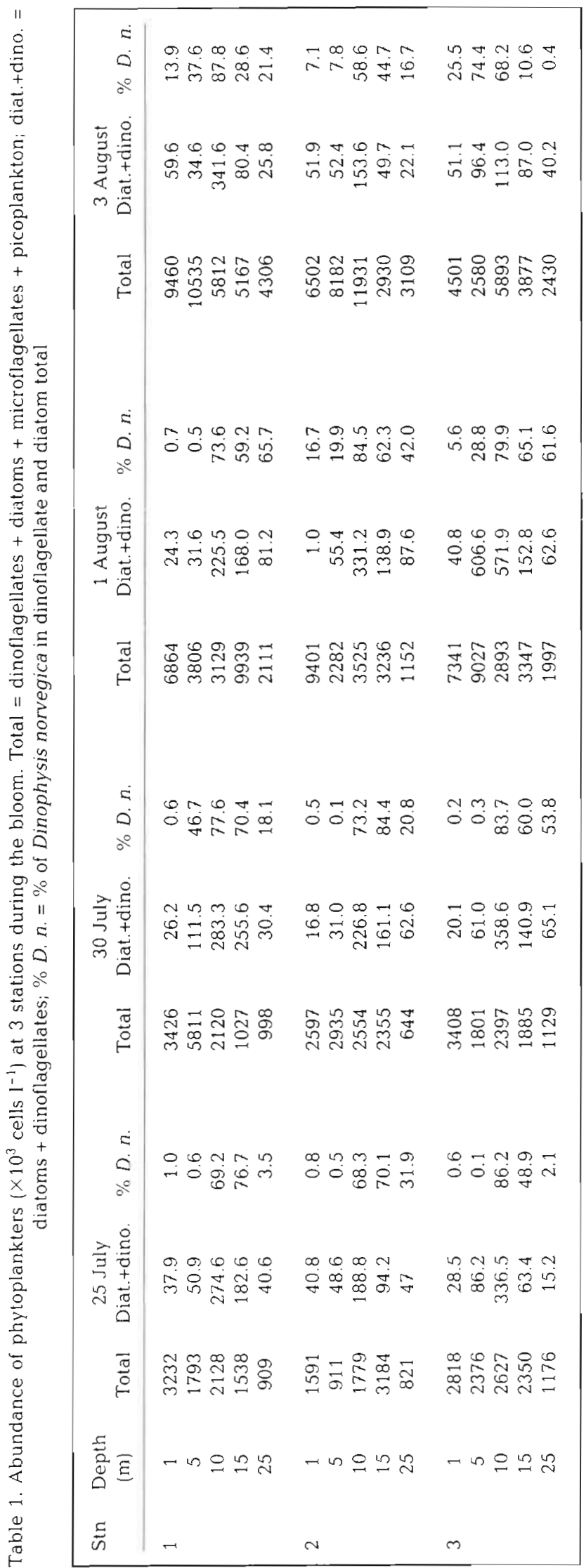

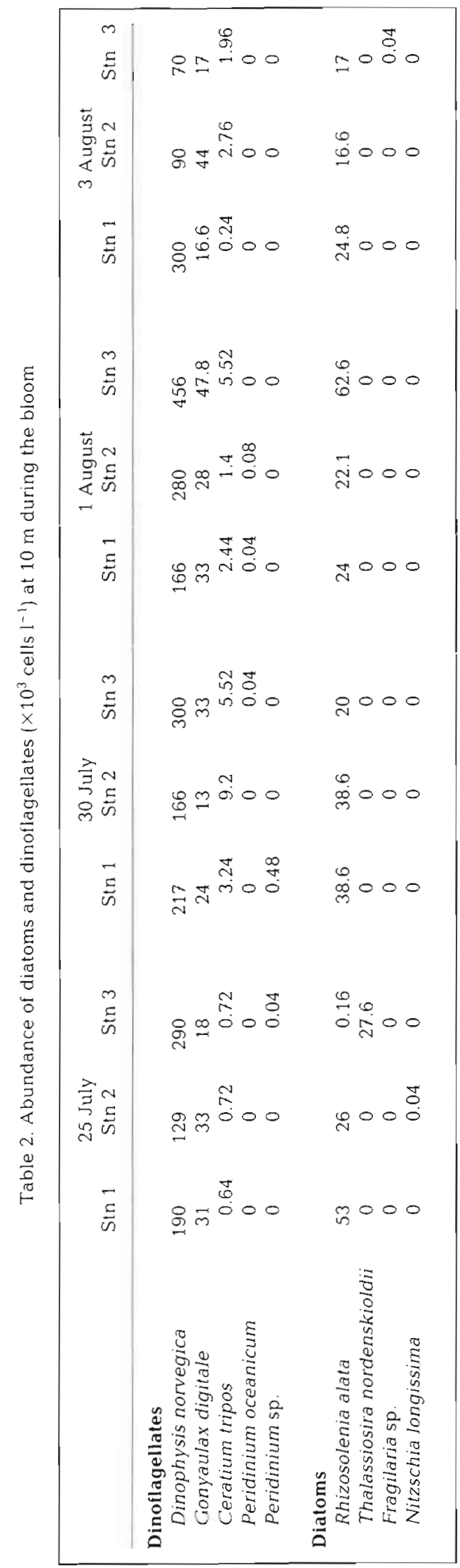


shine varied widely, $17.80 \mathrm{MJ}$ and $3.6 \mathrm{~h}$ on $25 \mathrm{July}$, $25.51 \mathrm{MJ}$ and $9.8 \mathrm{~h}$ on $30 \mathrm{July}, 2.83 \mathrm{MJ}$ and $0 \mathrm{~h}$ on 1 August and $26.87 \mathrm{MJ}$ and $13.6 \mathrm{~h}$ on 3 August. On 30 July and 3 August when the radiation was considerable, peaks of fluorescence were at 7 and $8 \mathrm{~m}$ respectively and were probably caused by an upward movement of phototactic dinoflagellates. This is consistent with the observations of Passow (1991) on another dinoflagellate.

Nutrients may not be regulating the bloom in Bedford Basin, which might be characterized as a giant chemostat (Platt 1975). None of the nutrients were exhausted during the red tide. At $10 \mathrm{~m}$, where maximum concentration of Dinophysis norvegica occurred, phosphates were between 0.86 and $0.94 \mu \mathrm{M}$; silicates, which apparently are not assimilated by dinoflagellates, between 0.16 and $0.60 \mu \mathrm{M}$. Below $10 \mathrm{~m}$, corresponding ranges were 0.56 to $1.01 \mu \mathrm{M}$ for phosphates and 0.60 to 5.95 for silicates. However, $\mathrm{NO}_{3}+\mathrm{NO}_{2}$ levels were seasonal and low, and ranged from 0.01 to $0.13 \mu \mathrm{M}$ at $10 \mathrm{~m}$; at 10 to $25 \mathrm{~m}$ depth, the values were between 0.13 and $1.79 \mu \mathrm{M}$. Our observations are in agreement with the findings of Delmas et al. (1992), who did not observe any nutrient exhaustion or any relationship between concentration of Dinophysis spp. and the availability of inorganic nutrients. In fact, the maximum concentrations of Dinophysis spp. were associated with nitrogen-impoverished waters. The low nitrogen levels in Bedford Basin waters during this bloom could be the result of its assimilation by the readily available nitrate reductase, demonstrated with red-tide samples of Gonyaulax polyedra (Eppley \& Harrison 1975) and in red-tide dinoflagellates off Peru (Dortch \& Maske 1982).

In the absence of pronounced wind mixing, the ag-

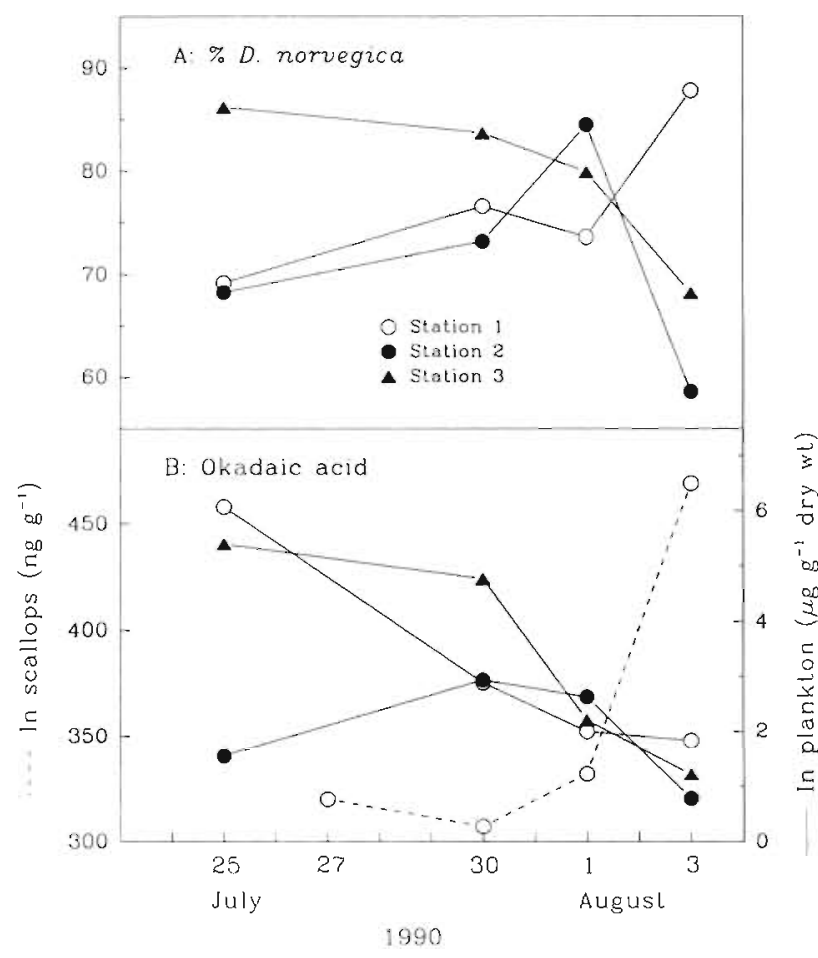

Fig. 7 Variations in (A) percentage of Dinophysis norvegica in net plankton and (B) toxin levels in scallop digestive glands and in plankton samples

gregation of Dinophysis norvegica around $10 \mathrm{~m}$ could be due to a strong density gradient. Such stratification $\left(\Delta \sigma_{\mathrm{T}}\right.$ ca 2 to 2.5 ) would suppress turbulence, resulting in $D$. norvegica aggregations. This is in conformity with the suggestion that in shallow depths (ca $30 \mathrm{~m}$ ), even a weak density gradient acted as a barrier to ver-

Table 3. Dinophysis norvegica. Abundance in selected waters

\begin{tabular}{|llll|}
\hline \multicolumn{1}{|c}{ Region } & Range $\left(\times 10^{3}\right.$ cells $\left.{ }^{-1}\right)$ & Season & Source \\
\hline Canadian Atlantic waters & & & Present study \\
$\quad$ Bedford Basin & $0.04-460$ & Jul-Aug 1990 & Platt \& Subba Rao (1970) \\
St. Margaret's Bay & $0.4-0.6$ & Apr 1969 & Subba Rao (1975) \\
Georges Bank & $0.3-2$ & Aug 1975 & Sita Devi (1980) \\
Malpeque Bay & $0.4-12.6$ & Jul 1973 & Gran \& Braarud (1935) \\
Gulf of Maine \& Bay of Fundy & Aapr-Sep & Wildish et al. (1990) \\
Bay of Fundy & $0.02-0.50$ & peaked during & Aug-Sep 1988 \\
& $0.02-1.64$ & Aug-Sep 1989 & Hansen (1989) \\
Denmark & 14 & 1985 & Séchet et al. (1990) \\
Norway & 81 & 1987 & Dahl \& Yndestad (1985) \\
Sweden & $0.1-2$ & June-Nov. & Edler \& Hageltorn (1990) \\
& $15-25$ & Nov-Dec 1984 & Krogh et al. (1985) \\
\hline
\end{tabular}


Table 4. DSP toxin levels in Dinophysis spp. DTX-1: dinophysistoxin-1; PTX-2: pectenotoxin-2; OA: okadaic acid

\begin{tabular}{|c|c|c|c|c|}
\hline Taxon & Location & Toxin & pg cell ${ }^{-1}$ & Source \\
\hline \multirow[t]{3}{*}{ D. fortii } & Mutsu Bay. Japan & DTX-1 & $13-191.5$ & \multirow[t]{9}{*}{ Lee et al. (1989) } \\
\hline & & PTX-2 & 42.5 & \\
\hline & Inland Sea, Japan & $\mathrm{OA}$ & 23 & \\
\hline D. mitra & Mutsu Bay, Japan & DTX-1 & 10 & \\
\hline D. rotundata & Mutsu Bay, Japan & DTX-1 & 101 & \\
\hline D. tripos & Kesennuma, Japan & DTX-1 & 36 & \\
\hline \multirow[t]{4}{*}{ D. acuta } & Vigo, Spain & $\mathrm{OA}$ & 9.4 & \\
\hline & Sogndal, Norway & $\mathrm{OA}$ & 4 & \\
\hline & & DTX-1 & 4.2 & \\
\hline & Gullmar Fjord, Sweden & $\mathrm{OA}$ & 20 & Edler \& Hageltorn (1990) \\
\hline \multirow[t]{5}{*}{ D. norvegica } & Arendal, Norway & $\mathrm{OA}$ & 0.8 & \multirow[t]{3}{*}{ Lee et al. (1989) } \\
\hline & & DTX-1 & 2.5 & \\
\hline & Sogndal, Norway & DTX-1 & 14.0 & \\
\hline & Bedford Basin, Canada & $\mathrm{OA}$ & $0.07-54.8$ & Present study \\
\hline & Guili of St. Lawrence, Canada & $\mathrm{OA}$ & $32.6 \pm 5.2$ & Cembella (1989) \\
\hline \multirow[t]{3}{*}{ D. accuminata } & Gulf of St. Lawrence, Canada & $\mathrm{OA}$ & $25.5 \pm 6.7$ & \multirow{3}{*}{$\begin{array}{l}\text { Cembella (1989) } \\
\text { Lee et al. (1989) }\end{array}$} \\
\hline & Le Havre, France & $\mathrm{OA}$ & 1.6 & \\
\hline & Tokyo Bay, Japan & $\mathrm{OA}$ & Trace & \\
\hline
\end{tabular}

tical migration of dinoflagellates (Blasco 1978). Off La Rochelle, France, Delmas et al. (1992) concluded that more than the inorganic nutrient input, stratification of sufficient magnitude $\left(\Delta \mathrm{T}>5{ }^{\circ} \mathrm{C},=\Delta \sigma_{\mathrm{T}}>1\right.$ at $\mathrm{S}=\mathrm{ca}$ $30 \%$ ) was necessary for Dinophysis spp. cell increase. Results of numerical modelling of Dinophysis spp. bloom in Vilaine Bay, southern Brittany, France (Menesguen et al. 1990) confirmed inhibition of Dinophysis spp. bloom by vertical turbulence.

Association of Dinophysis norvegica with OA has been reported (Table 4) in Arendal, Norway (Lee et al. 1989) and the Gulf of St. Lawrence, Canada (Cembella 1989). Cembella's observations were based on planktonic material harvested from repeated net tows (20 $\mu \mathrm{m}$ mesh) and the population density of $D$. norvegica was not reported. The work of Marr et al. (1992) was also based on the net tow samples and there were no data on the abundance of Prorocentrum lima in the seawater although it yielded OA under culture conditions. The present study is the first report of a DSP toxicogenic red tide due to $D$. norvegica in the Canadian Atlantic although this species has been in these waters since at least 1935 (Table 3 ).

It should be pointed out that Lee et al. (1989) reported the presence of both OA and DTX-1 in a sample of Dinophysis norvegica, while another sample of this species collected from Norway during the same month contained only DTX-1. There were other instances (Haamer et al. 1990) in which DSP toxins were apparently low in the samples containing high proportions of D. norvegica in excess of the critical concentration (200 cells $1^{-1}$ ) for DSP (Haigh \& Taylor 1990). This was also true in our samples. Plankton OA content decreased markedly between 25 July and 3 August at Stns 1 \& 3 , but not at Stn 2 (Fig. 7B). This decrease was parallel to the relative abundance of $D$. norvegica at $\operatorname{Stn} 3$, but not at Stn 1 (Fig. 7A). At Stn 2, however, there was general agreement between $\mathrm{OA}$ and $D$. norvegica relative abundance (Fig. 7A, B). Such a discrepancy may be due to the dependence of toxin production on the physiological state of the alga as shown for domoic acid (DA) production by Nitzschia pungens $\mathrm{f}$. multiseries (Bates et al. 1989, 1991, Subba Rao et al. 1990) and saxitoxins by Alexandrium tamarense (Anderson et al. 1990).

The cellular toxin levels in Dinophysis norvegica in this red tide varied considerably $(0.07$ to $54.77 \mathrm{pg}$ cell $\left.^{-1}\right)$ compared to $32.6 \pm 5.2 \mathrm{pg} \mathrm{cell}^{-1}$ reported in the Gulf of St. Lawrence bloom (Cembella 1989) or to 0.8 to $14.0 \mathrm{pg}$ cell $^{-1}$ in Norwegian waters (Lee et al. 1989).

The levels of OA in the bloom samples decreased significantly ( 3 times) as the bloom progressed but not in sea scallops Placopecten magellanicus that fed on the bloom populations (Fig. 7B). The scallops filtered on average $5.8 \mathrm{l}$ seawater $\mathrm{h}^{-1}(\mathrm{SD}=0.83, \mathrm{n}=10$; Cranford \& Gordon 1992j with 166 to $456 \times 10^{3} \mathrm{l}^{-1}$ Dinophysis norvegica. The presence of Dinophysis sp. did not inhibit the filtration rates and the scallops grew well during the bloom (Cranford \& Gordon 1992). In another study (Shumway et al. 1985), P. magellanicus selectively ingested another dinoflagellate, Prorocentrum minimum, from mixed cell assemblages 
Previously, large quantities of Dinophysis sp. have been found in the gut contents of scallops (Shumway et al. 1987). The level of OA in our sea scallops appears to be low compared to 410 to $5400 \mathrm{ng}^{-1}$ hepatopancreas of Mytilus edulis (Edebo et al. 1988). Assuming a minimum content of $10 \mathrm{pg} \mathrm{OA}$ cell ${ }^{-1}$ in $D$. norvegica, a scallop would filter 23.1 to $66.5 \times 10^{6}$ cells of $D$. norvegica per day, which would contain 231 to $665 \mu \mathrm{g}$ OA toxin. The actual $O A$ levels in scallops ranged from 307 to $469 \mathrm{ng} \mathrm{g}^{-1}$ tissue. These data suggest that scallops may have very low assimilation efficiencies of OA in the digestive tract. Wohlgeschaffen et al. (1992) showed that scallops accumulate DA more slowly and have a very low depuration rate for DA, tending to retain it longer compared to the blue mussel Mytilus edulis. The inverse relation in toxin contents between scallop samples and plankton samples suggests the accumulation of this toxin in the digestive tract of scallops even though there was a decrease of OA in the plankton.

Caution should be taken in interpreting DSP toxin on a cellular basis because of the presence of other possible DSP toxicogenic dinoflagellates. Also, the production of $\mathrm{OA}$ by Dinophysis norvegica may be related to the physiological stage of the alga. This dinoflagellate has so far not been amenable to culture. Thus, physiological studies on toxin production by Dinophysis sp. have lagged behind as in the case of Alexandrium tamarense and Nitzschia pungens f. multiseries. Therefore, at present, reporting DSP toxin associated with Dinophysis sp. on the basis of biomass (constant dry weight at $60^{\circ} \mathrm{C}$ ) would be preferable and would give a better comparison of DSP toxin in various environments.

Occurrence of the first recorded toxicogenic red tide in the Bedford Basin caused by Dinophysis norvegica suggests that a strong potential exists for the occurrence of a DSP in Canadian Atlantic waters. On the Grand Banks and Georges Bank, sea scallops along with mussels contribute substantially to an average annual fishing industry of Can $\$ 81$ million (Wohlgeschaffen et al. 1992) and occurrence of any toxicogenic bloom would have a significant impact. The high-risk season for a DSP event caused by $D$. norvegica in the north Atlantic region appears to be from June to November. More frequent sampling over longer periods is needed to promote a better understanding of the origin and development of red tides.

Acknowledgements. We are grateful to Drs K. H. Mann, D. C. Gordon Jr, J. E. Stewart, M. Sinclair and Mr G. D. Wohlgeschaffen for their interest and constructive criticism of the manuscript, and to 3 anonymous reviewers who made very helpful comments to improve the manuscript. Our special thanks are due to Mr P. J. Cranford for alerting us to the bloom, Coulter counting, supplying the scallops and for the comments on the manuscript. We thank Mr J. F. Amirault, Climatologist, Environmental Canada, for solar radiation data. $\mathrm{Y}$. Pan has been supported by a research grant to Dr K. H. Mann from Natural Sciences and Engineering Research Council of Canada.

\section{LITERATURE CITED}

Anonymous (1990). The PANTONE library of colour. PANTONE Process colour simulator 747XR, CYMK edn Pantone, Inc., Moonachie, NJ

Anderson, D. M., Kulis, D. M., Sullivan, J. J., Hall, S., Lee, C. (1990). Dynamics and physiology of saxitoxin production by the dinoflagellates Alexandrium spp. Mar. Biol. 104: $511-524$

Bates, S. S., Bird, C. J., deFreitas, A. S. W., Foxall, R., Gilgan, M. W., Hanic, L. A., Johnson, G. E., McCulloch, A. W., Odense, P., Pocklington, R., Quilliam, M. A., Sim, P. G., Smith, J. C., Subba Rao, D. V., Todd, E. C. D., Walter, J. A., Wright, J. L. C. (1989). Pennate diatom Nitzschia pungens as the primary source of domoic acid, a toxin in shellfish from eastern Prince Edward Island, Canada. Can. J. Fish. Aquat. Sci. 46: 1203-1215

Bates, S. S., deFreitas, A. S. W. Milley, J. E., Pocklington, R., Quilliam, M. A., Smith, J. C., Worms, J. (1991). Controls on domoic acid production by the diatom Nizschia pungens $\mathrm{f}$. multiseries in culture: nutrients and irradiance. Can. J. Fish. Aquat. Sci. 48: 1136-1144

Blasco, D. (1978). Observation on the diel migration of marine dinoflagellates off Baja California coast. Mar. Biol. 46: 41-47

Cembella, A. D. (1989). Occurrence of okadaic acid, a major diarrhetic shellfish toxin, in natural populations of Dinophysis spp. from the eastern coast of North America. J. appl. Phycol. 1: 307-310

Cranford, P. J., Gordon, D. C. Jr (1992). The influence of dilute clay suspensions on sea scallop (Placopecten magellanicus) feeding activity and tissue growth. Neth. J. Sea Res. 30: $107-120$

Dahl, E., Yndestad, M. (1985). Diarrhetic shellfish poisoning (DSP) in Norway in the autumn 1984 related to the occurrence of Dinophysis spp. In: Anderson, D. M., White, A. W., Baden, D. G. (eds.) Toxic dinoflagellates. Elsevier, New York, p. 495-500

Delmas, D., Herbland, A., Maestrini, S. Y (1992). Environmental conditions which lead to increase in cell density of the toxic dinoflagellates Dinophysis spp. in nutrient-rich and nutrient-poor waters of the French Atlantic coast. Mar. Ecol. Prog. Ser. 89: 53-61

Dortch, Q., Maske, M. (1982). Dark uptake of nitrate and nitrite reductase activity of a red-tide population off Peru. Mar. Ecol. Prog. Ser. 9: 299-303

Edebo, L., Lange, S., Li, X. P., Allenmark, S., Lindgren, K., Thompson, R. (1988). Seasonal, geographic and individual variation of okadaic acid content in cultivated mussels in Sweden. APMIS 96: 1036-1042

Edler, L., Hageltorn, M. (1990). Identification of the causative organism of a DSP outbreak on the Swedish west coast. In: Granéli, E., Sundström, B., Edler, L., Anderson, D. M. (eds.) Toxic marine phytoplankton. Elsevier, New York, p. $345-349$

Eppley, R. W., Harrison, W. G. (1975). Physiological ecology of Gonyaulax polyedra, a redwater dinoflagellate of southern California. In: LoCicero, V. R. (ed.) Proc. $1^{\text {st }}$ Int. Conf. 
on Toxic Dinoflagellates. Massachusetts Sci. Tech Foundation, Wakefield, p. 11-22

Freudenthal, A. R., Jijina, J. L. (1988). Potential hazards of Dinophysis to consumers and shellfisheries. J. Shellfish Res. 7: 695-701

Gran, H. H., Braarud, T (1935). A quantitative study of the phytoplankton in the Bay of Fundy and Gulf of Maine. J. biol. Bd Can. 1: 279-467

Haamer, J., Anderson, P. O., Lange, S., Li, X. P., Ebedo, L. (1990). Effects of transplantation and reimmersion of mussels Mytilus edulis Linnaeus, 1782 on their contents of okadaic acid. J. Shellfish Res. 9: 109-112

Haigh, R., Taylor, R. J. R. (1990). Distribution of potentially harmful phytoplankton species in the northern strait of Georgia, British Columbia. Can. J. Fish. Aquat. Sci. 47 $2339-2350$

Hansen, K. V. (1989). Occurrence of toxic, potential toxic plankton algae, plankton bloom including status for 1988 and the DSP/PSP mussel surveillance observation 1988. Report of the working group on harmful effects of algal blooms on mariculture and marine fisheries. Comm. Meet. Int. Coun. Explor. Sea C.M.-ICES/F:18, 21-30

Krogh, P., Edier, L., Graneli, E., Nyman, U. (1985). Outbreak of diarrhetic shellfish poisoning on the west coast of Sweden. In: Anderson, D. M., White, A. W., Baden, D. G. (eds.) Toxic dinoflagellates. Elsevier, New York, p. $501-503$

Lassus, P., Bardouil, M., Truquet, 1., Truquet, P., Lébaut, C., Pierre, M. J (1985). Dinophysis acuminata distribution and toxicity along the southern Brittany coast (France): correlation with hydrological parameters. In: Anderson, $D$ M., White, A. W., Baden, D. G. (eds.) Toxic dinoflagellates. Elsevier, New York, p. 159-164

Lee, J. S., Igarashi, T., Fraga, F., Dahl, E., Hovgaard, P., Yasumoto, T (1989). Determination of diarrhetic shellfish toxins in various dinoflagellate species. J. appl. Phycol. 1. $147-152$

Maranda, L., Shimizu, Y. (1987). Diarrhetic shellfish poisoning in Narragansett Bay. Estuaries 10: 298-302

Marr, J C., Jackson, A. E., McLachlan, J. L. (1992). Occurrence of Prorocentrum lima, a DSP toxin-producing species from the Atlantic coast of Canada. J. appl. Phycol. $4: 17-24$

Menesguen, A., Lassus, P., de Cremoux, F., Boutibonnes, L. (1990). Modelling Dinophysis blooms: a first approach. In: Granéli, E., Sundström, B., Edler, L., Anderson, D. M (eds.) Toxic marine phytoplankton. Elsevier, New York, p. $195-200$

Passow, U (1991). Vertical migration of Gonyaulax cateneta and Mesodinium runrum. Mar. Biol. 110: 455-463

Platt, T. (1975). Analysis of the importance of spatial and temporal heterogeneity in the estimation of annual production by phytoplankton in a small enriched marine basin. J. exp. mar. Biol. Ecol. 18: 99-109

Platt, T., Subba Rao, D. V. (1970). Primary production measurements on a natural. plankton bloom. J. Fish. Res. Bd Can. 27: 887-899

Quilliam, M. A., Gilgan, M. W., Pleasance, S., deFreitas, A. S. W., Douglas, D., Frits, L., Hu, T., Marr, J. C. Smyth, C., Wright, J. L. C. (1991). Confirmation of an incident of diarretic shellfish poisoning in eastern Canada. In: Gordon, D. C. Ir (ed.) Proc. $2^{\text {red }}$ Canadian Workshop on Harmful
Marine Algae. Can. Tech. Rep. Fish. Aquat. Sci. 1799, p. $18-22$

Séchet, V., Safran, P., Hovgaard, P., Yasumoto, T. (1990). Causative species of diarrhetic shellfish poisoning (DSP) in Norway. Mar. Biol. 105: 269-274

Sedmek, B., Fanuko, N. (1991). Occurrence of Dinophysis spp. and toxic shellfish in the Northern Adriatic. J. appl. Phycol. 3: 289-294.

Shestowsky, W. S., Quilliam, M. A., Sikorska, H. M. (1992). Anidiotypic-anti-idiotypic competitive immunoassay for quantitation of okadaic acid. Toxicon 30: 1441-1448

Shumway, S. E., Cucci, T J., Newell, R. C., Yentsch, C. M. (1985). Particle selection, ingestion and absorption in filter-feeding bivalves. J. exp. Mar. Biol. Ecol. 91: $77-92$

Shumway, S. E., Selvin, R., Schick, D. F. (1987). Food resources related to habitat in the scallop Placopecten magellanicus (Gmelin, 1791): a qualitative study. J. Shellfish Res. 6: 89-95

Sita Devi, J., (1980). Phytoplankton of Malpeque Bay, Prince Edward Island, Canada and the Welsh Dee Estuary, U.K. Ph.D thesis, Univ. Salford, Lancashire, U.K.

Strickland, J. D. H., Parsons, T. R. (1972). A practical handbook of seawater analysis. Bull. Fish. Res. Bd Can. 167

Subba Rao, D. V. (1975). Phytoplankton production, nutrients and density structure in the shelf area of Nova Scotia and Georges Bank during August 1974. Fish. Mar. Ser. Tech. Rep. 524

Subba Rao, D. V., deFreitas, A. S. W., Quilliam, M. A., Pocklington, R., Bates, S. S. (1990). Rates of production of domoic acid, a neurotoxic amino acid in the pennate marine diatom Nitzschia pungens. In: Granéli, E., Sundström, B., Edler, L., Anderson, D. M. (eds.) Toxic marine phytoplankton. Elsevier, New York, p. 413-417

Subba Rao, D. V., Smith, S. J. (1987). Temporal variation of size-fractionated primary production in Bedford Basin during the spring bloom. Oceanol. Acta 10: 101-1.09

Tubaro, A., Sosa, S., Bruno, M., Gucci, P. M. B., Volterra, L., Loggia, R. D. (1992). Diarrhetic shellfish toxins in Adriatic sea mussels evaluated by ELISA method. Toxicon 30 : 673-676

Uda, T., Itoh, Y., Nishimura, M., Usagawa, T., Murata, M., Yasumoto, $T$ (1989). Enzyme immunoassay using monoclonal antibody specific for diarrhetic shellfish poisons. In: Natori, S., Hashimoto, K., Ueno, Y (eds.) Mycotoxins and phycotoxins '88. Elsevier, New York, p. 335-342

White, A. W. (1986). High toxin content in the dinoflagellate Gonyaulax excavata in nature. Toxicon 24:605-610

White, A. W. Maranda, L. (1978). Paralytic toxin in the dinoflagellate Gonyaulax excavata and in shellfish. J Fish. Res. Bd Can. 35: 397-402

Wildish, D. J., Martin, J. L., Wilson, A. J., Ringuette, M. (1990) Environmental monitoring of the Bay of Fundy salmonoid mariculture industry during 1988-89. Can. Tech. Rep. Fish. Aquat. Sci. 1760

Wohlgeschaffen, G. D., Mann, K. H., Subba Rao, D. V. Pocklington, R. (1992). Dynamics of the phycotoxin domoic acid: accumulation and excretion in two commercially important bivalves. J. appl. Phycol. 4: 297-310

Yasumoto, T., Oshima, Y., Yamaguchi, M. (1978). Occurrence of a new type of shellfish poisoning in the Tohoku district. Bull. Jap. Soc. Sci. Fish. 44: 1249-1255 